\title{
HUMAN GLOMERULAR PERMEABILITY AND TUBULAR RECOVERY VALUES FOR HEMOGLOBIN
}

\author{
By ROGER K. MCDONALD, 1 JOHN H. MILLER, AND ELEANORE B. ROACH \\ (From the Section on Gerontology, National Heart Institute, National Institutes of Health, \\ P.H.S., F.S.A., Bethesda, Md., and the Baltimore City Hospitals, Baltimore, Md.)
}

(Submitted for publication May 16, 1951; accepted July 9, 1951)

Evidence for the glomerular filtration and tubular recovery of hemoglobin has been provided by several investigators (1-5). The simultaneous determination of hemoglobin and creatinine clearances in dogs and rabbits $(2,3)$ and of hemoglobin and inulin clearances in man has given ratios between 0.02 and 0.05 . These values have been interpreted as the permeability of the glomeruli to hemoglobin relative to creatinine or inulin. Harrison's studies on dogs indicated the glomerular permeability to hemoglobin was between 4 and 20 per cent of the permeability to creatinine (5). The capacity of the renal tubules for hemoglobin recovery varied between 4 and $45 \mathrm{mg} . / 100 \mathrm{cc}$. of glomerular filtrate.

The present study was undertaken primarily to determine the glomerular permeability and tubular recovery values for hemoglobin in the human kidney. In addition, the fact that hemoglobin and serum albumin may have approximately the same molecular weight, volume, and dissymmetry (6) suggested that the study of the glomerular permeability to hemoglobin might provide a means for determining the renal factors involved in the production of proteinuria.

\section{METHODS}

Subject selection criteria, the general test procedure, laboratory analyses and the preparation and administration of hemoglobin have been described previously (7). The subjects studied were placed into one of three groups depending upon the rate of administration of hemoglobin.

Rapid $(\mathrm{N}=9)$. All subjects received the commercially prepared hemoglobin solution ${ }^{2}$ in a single injection at a rate of about $1,400 \mathrm{mg} . / \mathrm{min}$. Six of the nine subjects were retested at intervals of two or more weeks to determine the reproducibility of the values obtained (Group II of reference 7).

1 Present address: U. S. Public Health Service Hospital, Wyman Park Drive, Baltimore 11, Maryland.

2 The hemoglobin solution used in part of this study was kindly provided by Sharp and Dohme, Inc., Glenolden, $\mathrm{Pa}$.
Intermediate $(\mathrm{N}=14)$. All subjects received an autogenous hemolyzed blood preparation in a single injection at a rate of about $700 \mathrm{mg}$. per minute (Group I of reference 7 ).

Slow $(\mathrm{N}=6)$. The commercially prepared hemoglobin solution was administered by slow infusion at a rate of about $60-70 \mathrm{mg} . / \mathrm{min}$. Five of the six subjects were retested at intervals of two or more weeks to determine the reproducibility of values (Group III of reference 7).

In all three groups arterial plasma and urine hemoglobin concentrations were determined for each urine collection period (8).

\section{RESULTS}

The relationship between the rate of urinary excretion of hemoglobin ( $Y$ ) to the plasma concen-

TABLE I

Values for glomerular permeability $(K), T m_{H b}$, and $T_{H b}$ obtained with a single injection of commercially prepared hemoglobin*

\begin{tabular}{|c|c|c|c|c|}
\hline Subject & Date & $\mathbf{K}$ & $T m_{\mathbf{H b}}$ & $T_{\mathbf{H b}}$ \\
\hline E. $\mathrm{H}$. & $\begin{array}{r}2 / 28 / 50 \\
6 / 6 / 50\end{array}$ & $\begin{array}{l}.12 \\
.11\end{array}$ & $\begin{array}{c}\text { mg. } H b / m i n . \\
13.2 \\
15.6\end{array}$ & $\begin{array}{c}\text { mg. Hb/100 cc. } \\
\text { filtrate } \\
19.1 \\
20.9\end{array}$ \\
\hline H. H. & $\begin{array}{r}2 / 1 / 50 \\
3 / 30 / 50\end{array}$ & $\begin{array}{l}.17 \\
.14\end{array}$ & $\begin{array}{l}26.5 \\
16.4\end{array}$ & $\begin{array}{l}25.2 \\
16.0\end{array}$ \\
\hline P. N. & $\begin{array}{r}1 / 4 / 50 \\
1 / 25 / 50\end{array}$ & $\begin{array}{l}.16 \\
.17\end{array}$ & $\begin{array}{l}16.6 \\
14.8\end{array}$ & $\begin{array}{l}21.2 \\
18.0\end{array}$ \\
\hline W. P. & $\begin{array}{l}12 / 7 / 49 \\
1 / 21 / 50\end{array}$ & $\begin{array}{l}.20 \\
.20\end{array}$ & $\begin{array}{l}21.3 \\
29.2\end{array}$ & $\begin{array}{l}25.0 \\
32.2\end{array}$ \\
\hline J. W. & $\begin{array}{r}12 / 7 / 49 \\
.3 / 7 / 50\end{array}$ & $\begin{array}{l}.19 \\
.14\end{array}$ & $\begin{array}{l}25.1 \\
16.7\end{array}$ & $\begin{array}{l}34.6 \\
20.0\end{array}$ \\
\hline R. H. & $\begin{array}{r}11 / 21 / 49 \\
1 / 19 / 50\end{array}$ & $\begin{array}{l}.23 \\
.14\end{array}$ & $\begin{array}{l}24.4 \\
13.4\end{array}$ & $\begin{array}{l}39.8 \\
15.7\end{array}$ \\
\hline W. T. & $3 / 1 / 50$ & .11 & 17.7 & 14.4 \\
\hline W. L. & $2 / 14 / 50$ & .15 & 17.0 & 21.8 \\
\hline F. B. & $12 / 14 / 49$ & .20 & 17.8 & 24.2 \\
\hline Mean & & .162 & 19.04 & 23.21 \\
\hline
\end{tabular}

* Each subject received 12 to $14 \mathrm{gm}$. of hemoglobin at an approximate rate of $1,400 \mathrm{mg}$./min. 


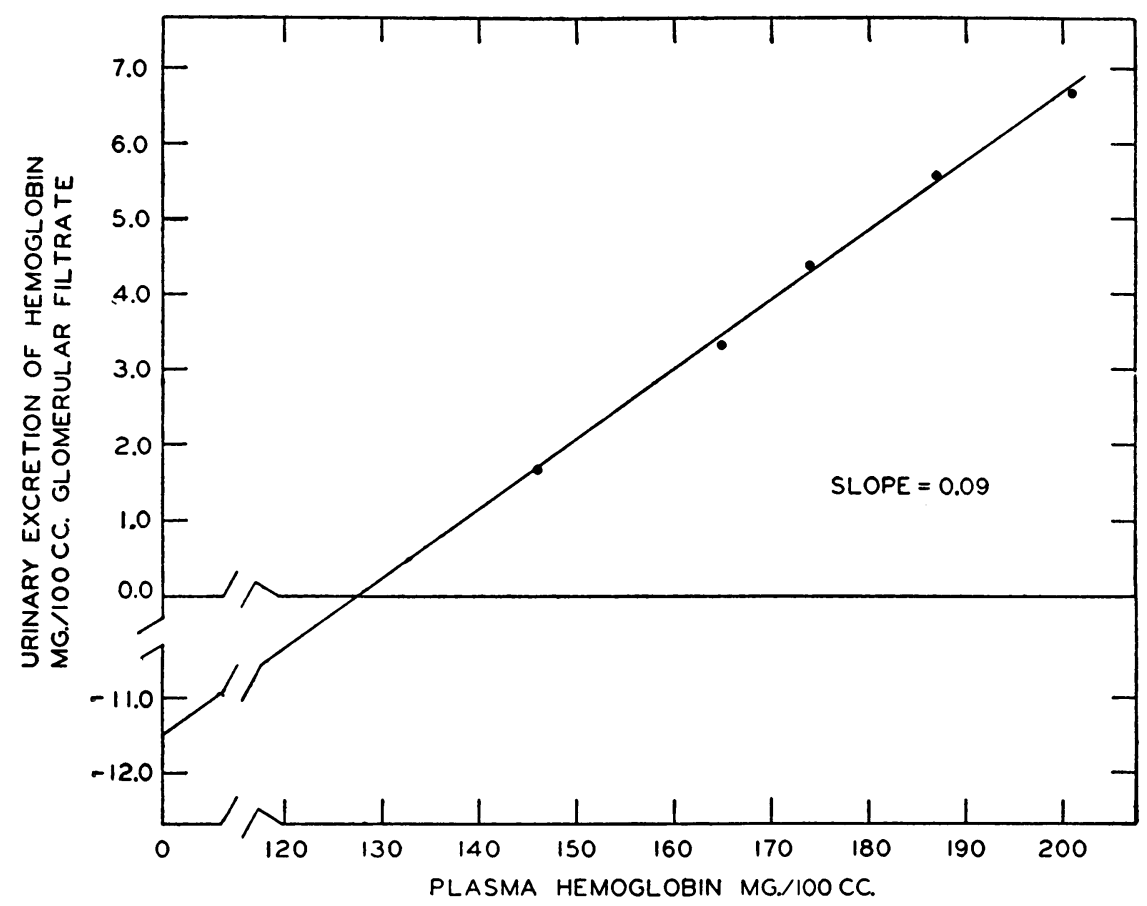

Fig. 1. The Relationship Between the Plasma Hemoglobin Concentration and the Urinary Excretion of Hemoglobin/100 cc. of Glomerular Filtrate

The $\mathrm{X}$ intercept of the linear function indicates the theoretical renal threshold. The $\mathrm{Y}$ intercept of the linear function indicates the tubular recovery of hemoglobin in mg./100 cc. of filtrate. Subject received $8.5 \mathrm{gm}$. of hemoglobin at a rate of $60 \mathrm{mg} . / \mathrm{min}$.

tration of hemoglobin (X) was rectilinear for all subjects ( $Y$ is expressed as urinary hemoglobin excretion in $\mathrm{mg} . / 100 \mathrm{cc}$. of glomerular filtrate;

TABLE II

Values for glomerular permeability $(K), T m_{H b}$, and $T_{H b}$ obtained with autogenous hemolyzed blood*

\begin{tabular}{|c|c|c|c|c|}
\hline Subject & Date & $\mathbf{K}$ & $\mathrm{Tm}_{\mathbf{H b}}$ & $\mathbf{T}_{\mathbf{H b}}$ \\
\hline $\begin{array}{l}\text { R. B. } \\
\text { S. D. } \\
\text { E. K. } \\
\text { T. B. } \\
\text { A. V. } \\
\text { A. B. } \\
\text { J. S. } \\
\text { P. D. } \\
\text { C. S. } \\
\text { E. H. } \\
\text { P. P. } \\
\text { W. P. } \\
\text { P. N. } \\
\text { W. L. }\end{array}$ & $\begin{array}{r}6 / 9 / 49 \\
6 / 20 / 49 \\
6 / 21 / 49 \\
6 / 24 / 49 \\
7 / 13 / 49 \\
7 / 21 / 49 \\
8 / 16 / 49 \\
8 / 17 / 49 \\
9 / 27 / 49 \\
10 / 20 / 49 \\
11 / 2 / 49 \\
11 / 20 / 49 \\
12 / 19 / 49 \\
1 / 3 / 50\end{array}$ & $\begin{array}{l}.07 \\
.08 \\
.16 \\
.13 \\
.12 \\
.10 \\
.14 \\
.20 \\
.10 \\
.10 \\
.10 \\
.10 \\
.20 \\
.15\end{array}$ & $\begin{array}{c}\text { mg. } H b / m i n . \\
3.1 \\
8.4 \\
18.0 \\
14.1 \\
8.2 \\
12.2 \\
14.0 \\
20.8 \\
20.8 \\
13.2 \\
4.3 \\
11.8 \\
17.6 \\
20.1\end{array}$ & \begin{tabular}{|c} 
mg. Hb/100 cc. \\
filtrate \\
5.7 \\
13.0 \\
29.2 \\
16.5 \\
11.2 \\
12.9 \\
19.2 \\
28.8 \\
16.5 \\
18.1 \\
7.1 \\
10.2 \\
22.2 \\
16.9
\end{tabular} \\
\hline Mean & & .125 & 13.10 & 16.50 \\
\hline
\end{tabular}

* Each subject received from 12 to $15 \mathrm{gm}$. of hemoglobin at an approximate rate of $700 \mathrm{mg} . / \mathrm{min}$.
$\mathrm{X}$ as $\mathrm{mg}$. hemoglobin/100 cc. plasma). Figure 1 shows the plot obtained for a single subject, E. H. This relation is of the form $Y=K X+T$, where the slope $\mathrm{K}$ indicates permeability of the glomeruli to hemoglobin relative to inulin. $T_{\mathbf{H b}}$ is the $\mathrm{Y}$ intercept and represents the tubular component of hemoglobin excretion in $\mathrm{mg} . / 100 \mathrm{cc}$. of glomerular filtrate. $T_{\mathbf{H b}}$ is negative, indicating that the tubules remove hemoglobin from the filtrate. $T_{\mathbf{H b}} / \mathrm{K}$ is the $\mathrm{X}$ intercept which represents the theoretical renal threshold for hemoglobin. $T \mathrm{~m}_{\mathrm{Hb}}$ for the individual (expressed in mg. hemoglobin per minute), is obtained by multiplying the $T_{\mathbf{H b}}$ in $\mathrm{mg}$. hemoglobin/cc. glomerular filtrate by the average glomerular filtration rate $\left(\mathrm{C}_{\mathrm{IN}}\right)$.

The derived renal threshold values for groups designated as Rapid, Intermediate and Slow were $148.2 \pm 42.0,133.7 \pm 31.0$, and $96.4 \pm 25.5 \mathrm{mg}$. of hemoglobin/100 cc. of plasma. The renal thresholds for the Rapid and Intermediate groups were significantly higher than that of the Slow group $(\mathrm{P}<.01)$. 
The results obtained for $K, T_{\mathrm{Hb}} / 100 \mathrm{cc}$. of filtrate and $T m_{H b}$ are shown in Tables I, II, and III. The mean $\mathrm{K}(0.162)$ for the Rapid group (Table I) was significantly higher than the mean $\mathrm{K}$ of 0.101 for the Slow group ( $\mathrm{P}<.01$-Table III).

The mean $\mathrm{Tm}_{\mathrm{Hb}}$ of $19.04 \mathrm{mg} . / \mathrm{min}$. for the group that received the single rapid injection of the commercial hemoglobin solution was significantly higher than the $\mathrm{Tm}_{\mathrm{Hb}}$ for either the Intermediate group (13.10 $\mathrm{mg} . / \mathrm{min}$.-Table II) or for the Slow group ( $9.07 \mathrm{mg} . / \mathrm{min}$.-Table III). During the periods of time in which our subjects were studied, the tubular recovery of hemoglobin was not only constant per unit of filtrate in a given individual throughout the experimental procedure but was also apparently operative at a maximum rate since it remained constant as the plasma level of hemoglobin changed and the load of hemoglobin presented for tubular recovery varied.

Although the graphic estimation of $K$ and $T_{\mathbf{H b}}$ gave highly reliable results when applied to the data of a single experiment, ${ }^{3}$ it can be seen from Table II and III that the values obtained on different days in the same subject tended to vary widely. Indeed, duplicate tests on subjects P. N., W. P.,

8 The correlation coefficient for values of $\mathrm{K}$ derived independently by two observers using the same experimental data was 0.98 .

TABLE III

Values for glomerular permeability $(K), T m_{H b}$, and $T_{H b}$ obtained with a slow infusion of commercially prepared hemoglobin solution*

\begin{tabular}{|c|c|c|c|c|}
\hline Subject & Date & $\mathbf{K}$ & $\mathrm{Tm}_{\mathbf{H b}}$ & $\mathrm{T}_{\mathbf{H b}}$ \\
\hline E. H. & $\begin{array}{l}1 / 30 / 50 \\
5 / 10 / 50\end{array}$ & $\begin{array}{l}.07 \\
.09\end{array}$ & $\begin{array}{c}\text { mg. } H b / m i n . \\
6.7 \\
9.2\end{array}$ & \begin{tabular}{|c} 
mg. $H b / 100 c c$. \\
filtrate \\
8.4 \\
11.4
\end{tabular} \\
\hline H. H. & $\begin{array}{l}2 / 23 / 50 \\
4 / 13 / 50\end{array}$ & $\begin{array}{l}.15 \\
.14\end{array}$ & $\begin{array}{l}13.9 \\
15.8\end{array}$ & $\begin{array}{l}14.7 \\
14.9\end{array}$ \\
\hline P. N. & $\begin{array}{r}2 / 15 / 50 \\
3 / 6 / 50\end{array}$ & $\begin{array}{l}.12 \\
.08\end{array}$ & $\begin{array}{l}6.3 \\
5.8\end{array}$ & $\begin{array}{l}7.4 \\
5.7\end{array}$ \\
\hline W. P. & $\begin{array}{l}1 / 31 / 50 \\
2 / 20 / 50\end{array}$ & $\begin{array}{l}.12 \\
.05\end{array}$ & $\begin{array}{l}9.7 \\
1.7\end{array}$ & $\begin{array}{r}11.6 \\
1.7\end{array}$ \\
\hline J. W. & $\begin{array}{l}1 / 25 / 50 \\
2 / 14 / 50\end{array}$ & $\begin{array}{l}.08 \\
.14\end{array}$ & $\begin{array}{r}6.9 \\
13.8\end{array}$ & $\begin{array}{r}8.1 \\
16.5\end{array}$ \\
\hline W. T. & $2 / 8 / 50$ & .07 & 10.0 & 7.8 \\
\hline Mean & & .101 & 9.07 & 9.84 \\
\hline
\end{tabular}

* Each subject received hemoglobin at a rate of 60 to $70 \mathrm{mg} . / \mathrm{min}$. and J. W. (Table III) differed to a greater extent than did any of their values from the group mean. The potential effect of differences in urine flow on the results of duplicate tests was determined and found to be considerably less than one per cent.

In several subjects, serial examination of the urine specimens obtained following the injection of hemoglobin revealed a microscopic hematuria of variable intensity but never sufficiently great to cause a significant alteration in the urine hemoglobin values.

\section{DISCUSSION}

The term glomerular permeability $(K)$ is not used in the absolute sense but is used as the permeability of the glomerular bed to hemoglobin relative to its permeability to inulin. Other workers (2-4) have expressed relative permeability as the ratio of the clearance of hemoglobin to the clearance of creatinine in dogs or to the clearance of inulin in humans. This method fails to take into account the factor of tubular recovery. The ratio $\mathrm{C}_{\mathrm{Bb}} / \mathrm{C}_{\mathrm{IN}}$ approaches the true permeability, $\frac{\mathrm{U}_{\mathbf{H b}}+\mathrm{Tm}_{\mathrm{Hb}}}{\mathrm{P}_{\mathbf{H b}} \mathrm{C}_{\mathrm{IN}}}$, asymptotically as the plasma hemoglobin concentration $\left(\mathrm{P}_{\mathbf{H b}}\right)$ increases. The plasma hemoglobin concentrations used in the present study were of the order of twice the renal threshold (200-300 mg./100 cc.) and the use of the clearance ratio method would have given $K$ values for hemoglobin about half of the actual values obtained. Plasma hemoglobin values ten times the renal threshold (1000-1500 mg. per cent) would be required to give ratios equal to 90 per cent of the true permeability values. The results of our observations on humans are in much closer agreement with the canine values obtained by Harrison (5), who also derived the $\mathrm{K}$ values for hemoglobin in the manner shown in Figure 1, than they are with the values for human subjects obtained by Brandt, Frank, and Lichtman (4) using the clearance ratio method.

The glomerular permeability constants for hemoglobin obtained in the present study would be inordinately high if applied to plasma albumin, since approximately 0.5 to $1.0 \mathrm{gm}$. of protein would then be filtered each minute by the glomer- 
uli of the normal human kidney.4 Analysis of glomerular filtrate using a method sensitive to about $30 \mathrm{mg}$. per cent in the mammalian kidney has failed to demonstrate the consistent presence of protein $(11,12)$. In rabbits protein concentrations of 15 to $22 \mathrm{mg}$. per cent in the glomerular filtrate have been demonstrated (13). This protein concentration would suggest a permeability constant not greater than 0.005 for plasma albumin. Thus it is apparent that the glomerular permeability to hemoglobin obtained under the conditions of this study differs significantly from the permeability to plasma albumin in spite of the fact that both substances are structurally similar (6).

The pronounced decrease in glomerular filtration rate and renal blood flow resulting from the intravascular administration of hemoglobin (7) suggests an explanation for the high $\mathrm{K}$ values for hemoglobin obtained in this study. The decreases in renal blood flow were of sufficient magnitude to produce a marked ischemia in a number of glomeruli. That a change in permeability suffcient to allow a significant leakage of plasma protein out of capillaries can be produced by a few minutes of ischemia or anoxic anoxia has been demonstrated $(14,15)$. The observation that a delay period of four to 25 minutes elapsed between the end of the rapid injection of hemoglobin and the appearance of hemoglobinuria is consistent with an ischemia of some glomeruli with subsequent increased permeability when blood flow is reestablished. The fact that the glomerular permeability to hemoglobin was significantly higher when the individuals received a single rapid injection than when they received a slow infusion supports this speculation; for only with the rapid administration of hemoglobin was there an intense, initial renal vasoconstriction (7). The association of proteinuria with decreased glomerular filtration rate and renal blood flow has been observed by others $(16,17)$. Especially pertinent to this hypothesis is the observation of White and Rolf (16) that during heavy exercise a group of normal subjects developed a marked decrease in glomerular

\footnotetext{
4 It is possible that some degree of dissociation of the hemoglobin molecule might occur at the low plasma concentrations employed in this study $(9,10)$, but the absence of any quantitative information on this possibility precludes consideration here.
}

filtration rate and renal blood flow. Before and during the exercise the urine was free of protein, but urine formed in the first and second postexercise periods ( 40 minutes after exercise) contained protein.

The variations in tubular recovery of hemoglobin noted between individuals and between repeat determinations on the same individual were associated with parallel changes in the glomerular permeability. This observation is also in accord with the concept that the filtration of hemoglobin was inordinately high in those glomeruli whose permeability characteristics were altered to some degree by ischemia. The greater the number of glomeruli filtering hemoglobin, the greater the number of tubules that would participate in recovery, and the greater would be the rate of tubular recovery as determined for the kidney as a whole.

The coexistence of high renal thresholds for hemoglobin and high glomerular permeability to hemoglobin is an apparent paradox. The term, renal threshold, is a value dependent upon three variables, viz., glomerular permeability, glomerular filtration rate and tubular recovery. The presence of the highest renal thresholds in the subjects with the highest glomerular permeability to hemoglobin indicates that the tubular recovery is sufficiently high to prevent hemoglobinuria from occurring at the lower plasma levels. This finding may be interpreted to mean that with greater renal ischemia less filtrate is available per nephron filtering hemoglobin and the tubules are thus able to recover the filtered hemoglobin more completely.

Finally, it is suggested that on the basis of the findings of the present study, the intravascular administration of hemoglobin increases the glomerular permeability to protein. For this reason hemoglobin does not appear to be a satisfactory tool for the study of glomerular permeability in the normal or the diseased kidney.

\section{SUMMARY AND CONCLUSIONS}

The mechanism of hemoglobin excretion by the human kidney has been studied in 19 subjects. It is concluded that hemoglobin is filtered by the glomeruli and recovered by the tubules to a limited extent. The glomerular permeability to hemoglobin was significantly lower $(K=0.101)$ when 
hemoglobin was administered at a slow rate (70 $\mathrm{mg} . / \mathrm{min}$.) than when it was administered at a rapid rate $(1,400 \mathrm{mg} . / \mathrm{min}$. $)(\mathrm{K}=0.162)$. The permeability of the glomeruli to hemoglobin averaged 12.9 per cent of the glomerular permeability to inulin. The renal tubular recovery of hemoglobin averaged $17.1 \mathrm{mg}$. per $100 \mathrm{cc}$. of glomerular filtrate.

It is suggested that the intravascular administration of hemoglobin alters glomerular permeability. How this effect is mediated is unknown, but the sequence of renal vasoconstriction followed by ischemic alteration of glomerular capillaries seems likely.

\section{ACKNOWLEDGMENTS}

It is a pleasure to acknowledge those who provided valuable assistance in carrying out this study. The method of determining the glomerular permeability to hemoglobin was suggested by Dr. Harold E. Harrison. Dr. Milton Landowne offered valuable suggestions and criticism. The laboratory analyses were made by Mrs. Elsie Beard, Mr. Charles Punte, and Mr. Robert Faid.

\section{REFERENCES}

1. Gerard, P., Comparative histophysiology of the vertebrate nephron. J. Anat., 1936, 70, 354.

2. Monke, J. V., and Yuile, C. L., The renal clearance of hemoglobin in the dog. J. Exper. Med., 1940, 72, 149.

3. Brandt, J. L., and Gruhn, J. G., Effect of renin on proteinuria and PAH clearance at low plasma levels. Am. J. Physiol., 1948, 153, 458.

4. Brandt, J. L., Frank, R., and Lichtman, H. C., Normal hemoglobin clearances in chronic proteinuria. Proc. Soc. Exper. Biol. \& Med., 1950, 74, 863.
5. Harrison, H. E., Personal communication.

6. Svedberg, T., Ultracentrifugale dispersitatsbestimmungen an eiweisslosungen. Kolloid-Ztschr., 1930, 51, 10.

7. Miller, J. H., and McDonald, R. K., The effect of hemoglobin on renal function in the human. J. Clin. Invest., 1951, 30, 1033.

8. Evelyn, K. A., and Malloy, H. T., Microdetermination of oxyhemoglobin methemoglobin and sulphemoglobin in a single sample of blood. J. Biol. Chem., 1938, 126, 655.

9. Tiselius, A., and Gross, D., Messengen der diffusion von eiweisskörpern. Kolloid-Ztschr., 1934, 66, 11.

10. Steinhardt, J., Properties of hemoglobin and pepsin in solutions of urea and other amides. J. Biol. Chem., 1938, 123, 543.

11. Wearn, J. T., and Richards, A. N., Observations on the composition of glomerular urine with particular reference to the problem of reabsorption in the renal tubules. Am. J. Physiol., 1924, 71, 209.

12. Walker, A. M., and Oliver, J., Methods for the collection of fluid from single glomeruli and tubules of mammalian kidney. Am. J. Physiol., 1941, 134, 562.

13. Dock, W., Proteinuria and the associated renal changes. New England J. Med., 1942, 227, 633.

14. Landis, E. M., Micro-injection studies of capillary permeability; effect of lack of oxygen on permeability of the capillary wall to fluid and to plasma protein. Am. J. Physiol., 1928, 83, 528.

15. Henry, J., Goodman, J., and Meehan, J., Capillary permeability in relation to acute anoxia and to venous oxygen saturation. J. Clin. Invest., 1947, 26, 1119.

16. White, H. L., and Rolf, D., Effects of exercise on renal circulation. Federation Proc., 1948, 7, 133.

17. Javitt, N. B., and Miller, A. T., Jr., Relation of glomerular filtration rate and blood and urine $\mathrm{pH}$ to physiologic proteinuria. Federation Proc., 1951, $10,70$. 